University of Nebraska - Lincoln

DigitalCommons@University of Nebraska - Lincoln

3-1995

\title{
Reproductive Structure and Organogenesis in a Cottonwood, Populus deltoides (Salicaceae)
}

Robert B. Kaul

University of Nebraska-Lincoln

Follow this and additional works at: https://digitalcommons.unl.edu/bioscifacpub

Part of the Biology Commons, and the Botany Commons

Kaul, Robert B., "Reproductive Structure and Organogenesis in a Cottonwood, Populus deltoides (Salicaceae)" (1995). Faculty Publications in the Biological Sciences. 851.

https://digitalcommons.unl.edu/bioscifacpub/851

This Article is brought to you for free and open access by the Papers in the Biological Sciences at DigitalCommons@University of Nebraska - Lincoln. It has been accepted for inclusion in Faculty Publications in the Biological Sciences by an authorized administrator of DigitalCommons@University of Nebraska - Lincoln. 


\title{
REPRODUCTIVE STRUCTURE AND ORGANOGENESIS IN A COTTONWOOD, POPULUS DELTOIDES (SALICACEAE)
}

\author{
ROBERT B. KAUL \\ Biological Sciences, University of Nebraska, Lincoln, Nebraska 68588-0118
}

\begin{abstract}
The organogenesis of inflorescences, flowers, and fruits was followed for $2 \mathrm{yr}$ in a male and a female tree of eastern cottonwood, Populus deltoides. Soon after anthesis, an inflorescence for the next year is initiated as a continuation of the apical meristem in most axillary buds of the extension shoot of the current year. Bract and then floral primordia arise helically, and by the end of summer all floral appendages are evident. Individual perianth parts are evident early in ontogeny but not at anthesis; they are vascularized independently by distal traces of discrete vascular strands that also serve the androecium or gynoecium. The stamens arise and are vascularized in centrifugal order, the first- and last-formed stamens receiving their traces from the proximal and subdistal divisions, respectively, of the discrete vascular strands serving groups of stamens. There is no external evidence of stamen fascicles. Centrifugal polyandry is interpreted as a derived state in Populus. The usual number of carpels in $P$. deltoides is three, but two and four are not rare, and two is probably the plesiomorphic state for the genus.
\end{abstract}

\section{Introduction}

The Salicaceae-Salix, the willows, and Populus, the cottonwoods and aspens - are now rather tentatively placed near the Flacourtiaceae in the Dilleniidae or equivalent taxon (Meeuse 1975; Takhtajan 1980; Cronquist 1988; Thorne 1992). Their reproductive structure-a likely source of phylogenetically useful information - is not fully understood but is known in some detail for a few species of Populus, especially $P$. alba and P. tremula in Europe and P. tremuloides and P. deltoides in North America. For some species, microscopic details of the pollen, embryo sac, and embryo are known (Graf 1921; Fisher 1928; Nagaraj 1952; Hejnowicz 1976), and submicroscopic and molecular details of reproduction have been described by Villar et al. (1987), Russell et al. (1990), and Christian et al. (1993).

Development and vascular anatomy of flowers and inflorescences of various species of Populus were shown by Graf (1921), Hjelmqvist (1948), Lester (1963), Sattler (1973), Hong et al. (1987), and Boes and Strauss (1994). Nagaraj's (1952) study used paraffin sections to present developmental details of $P$. deltoides but did not address some aspects. Here I report on the reproductive organogenesis and structure of $P$. deltoides as recorded by SEM in order to clarify the time and place of origin and function of structures and to provide morphological evidence of phylogenetic value.

Populus deltoides Bartram ex Marshall, eastern cottonwood, is a common dioecious tree from the Great Plains to the east coast and from the Canadian prairies to the Gulf coast (Little 1971). It is the only member of its genus over much of its range, including the area from which my sam-

Manuscript received August 1994; revised manuscript received October 1994. ples were taken, but it hybridizes with some congeners at its northern and western limits (Eckenwalder 1984a). It is most abundant and reaches largest size on alluvial soils, but it thrives in drier uplands as well.

Female and male trees of $P$. deltoides occur in equal numbers (Farmer 1964; Kaul and Kaul 1984), and the sex ratio is the same in lowland and upland habitats and remains unchanged over time within populations (Kaul and Kaul 1984). Male trees grow taller but do not have thicker trunks than female trees (Farmer 1964). Cottonwood trees are heavily floriferous every year; Bessey (1904), analyzing a $12 \mathrm{~m}$ tall tree near my study site, calculated that it produced $32,000 \mathrm{fe}-$ male catkins and 28,000,000 seeds each year.

\section{Material and methods}

I collected buds and inflorescences from twigs $4 \mathrm{~m}$ above ground from a male and a female tree at weekly intervals from March through September for 2 yr, 1992 and 1993, and I made biweekly collections from October through February. The trees are on alluvial soil in Lancaster County, Nebraska, and are at least $40 \mathrm{yr}$ old. They produce abundant flowers and fruits every year.

I cut off the sharp tip of each bud and then aspirated the buds in formalin-propionic acidethanol-water $(2: 1: 10: 3.5)$ fixative (FPA). After several weeks in the fixative, the buds were dissected by removing the hard bud scaies and sometimes also the soft floral bracts. Specimens destined for SEM were critical-point dried and sputter-coated for $5 \mathrm{~min}$ with gold-palladium. SEM images were computer-digitized and processed for sharpness and contrast. For observation of vascular tissues, some specimens were cleared in $5 \% \mathrm{NaOH}$ at $54^{\circ} \mathrm{C}$ for ca. $24 \mathrm{~h}$, rinsed in water, and placed in $85 \%$ lactic acid for viewing with combinations of transmitted and reflected light. 


\section{Results}

\section{BuDs}

In male and female trees, a single fertile (floriferous) or sterile (branch-forming) bud forms in the axil of most leaves and is evident even before those leaves mature. Some of the first-formed (proximal) and often the last-formed (distal) axillary buds of an extension shoot are sterile but produce leafy proleptic branches in their second year. Thus, each axillary bud produces either an inflorescence or a leafy shoot, the flowers thus arising on the shoot of the previous year. The terminal bud, which is covered by cataphyll-like stipules (Curtis and Lersten 1974), produces only the extension shoot but no flowers in its first year.

The fertile winter bud is a layered, resinous chamber for the primordial inflorescence within. The thick and strong bud scales of axillary buds cover the imbricated floral bracts, which themselves obscure the floral primordia as the buds enter winter dormancy. The scales are photosynthetic, and with the approach of winter the sticky resin hardens, sealing the bud and giving it its yellow-brown color.

\section{INFLORESCENCE DEVELOPMENT}

Soon after anthesis in April, the apical meristem in each developing bud that will produce next year's flowers first produces the bud-scale primordia and then becomes the meristem of the single terminal inflorescence (figs. 1, 2, 13). In primordia of female and male inflorescences, the earliest, lowest of the helically arising bract primordia (figs. 1, 13) are evident by late June and are followed by the others in acropetal order. All bract primordia are evident in early August. In some buds one or two of the lowest floral bracts are much larger than the others, sometimes extending to the tip of the primordial inflorescence in its bud, and are intermediate in morphology between floral bracts and bud scales.

The floral bract primordia arise directly from the inflorescence rachis. The early, proximal bract primordia quickly widen and become fimbriate, and they are imbricated well before the later more distal primordia are evident (figs. 2, 13). By midAugust, growth ceases for the year and the bracts have developed the long fimbriations that collectively form a thin but rather tight mat over all the primordia (fig. 3). By this time the single floral primordium in the axil of each bract has recognizable primordia of the perianth and androecium or gynoecium (e.g., figs. $2,4,14$ ).

\section{MALE INFLORESCENCES AND FLOWERS}

ANTHESIS. In early April, about 2 wk before the terminal bud breaks, each inflorescence emerges from its bud, distal flowers first. The anthers become maroon-red with exposure, giv- ing the entire inflorescence its characteristic dark red color, but the unexposed anthers toward the rachis remain pale yellow. The mature androecium consists of stamens crowded rather evenly on a somewhat concave receptacle (figs. 7,8 ). The floral bracts by this time have been elevated on the flower pedicels and are no longer sessile on the rachis (fig. 8). The inflorescence droops catkin-like as anthesis progresses, its rachis elongating and its flowers becoming less crowded. The bracts fall with anthesis of the odorless flowers, which is in basipetal order on the raceme. After anthesis, the rachis falls with its spent flowers attached and the bud, having lost its scales, is represented only by a scar on the stem, just above the scar of the leaf that subtended it.

The perianth in anthesis is represented by a continuous and unevenly undulate ridge of green tissue around the androecium (figs. 3, 7, 8). There were no vestigial gynoecia in flowers of the tree I studied, but occasionally a few flowers of a nearby male tree bore one or two carpellodia, some with stigmas.

ORGANOGENESIS. The rather flat and featureless early primordium of the male flower (figs. 2, 4,5 ) expands faster on its flanks than in its radial plane and soon becomes vaguely angular. The first tepal primordium arises closest to the inflorescence axis, and the others arise more or less simultaneously soon after (figs. 4-6). Together, all tepal primordia encircle the receptacle and are distinct in the early stages. Later they form an uneven, continuous ridge on the periphery of the receptacle and the identity of individual tepals is lost (figs. 7, 8).

The first stamen primordium appears slightly abaxial of the center of the receptacle (fig. 5), and a second one soon arises beside it. Others quickly follow in centrifugal sequence (fig. 6) and all stamen primordia are present by late July (figs. 3, 7).

The primordial anthers reach the tetrasporangiate, microspore mother cell stage by late $\mathrm{Au}$ gust, but the filaments are barely evident then (fig. 7). Growth ceases for the winter, to resume the following March, when meiosis proceeds basipetally on the inflorescence. The first (distal) flowers to emerge from the opening bud have free pollen grains, but those below it are yet in the tetrad stage.

Meiosis is essentially synchronous among the stamens in a flower, as expected, because all stamens are equally developed when meiosis begins. Anther dehiscence, however, is not necessarily synchronous within a flower, nor does it always parallel the centrifugal sequence of stamen origin. Various patterns - centrifugal, centripetal, synchronous, and random - are evident, sometimes all within a single catkin. Catkins brought into 


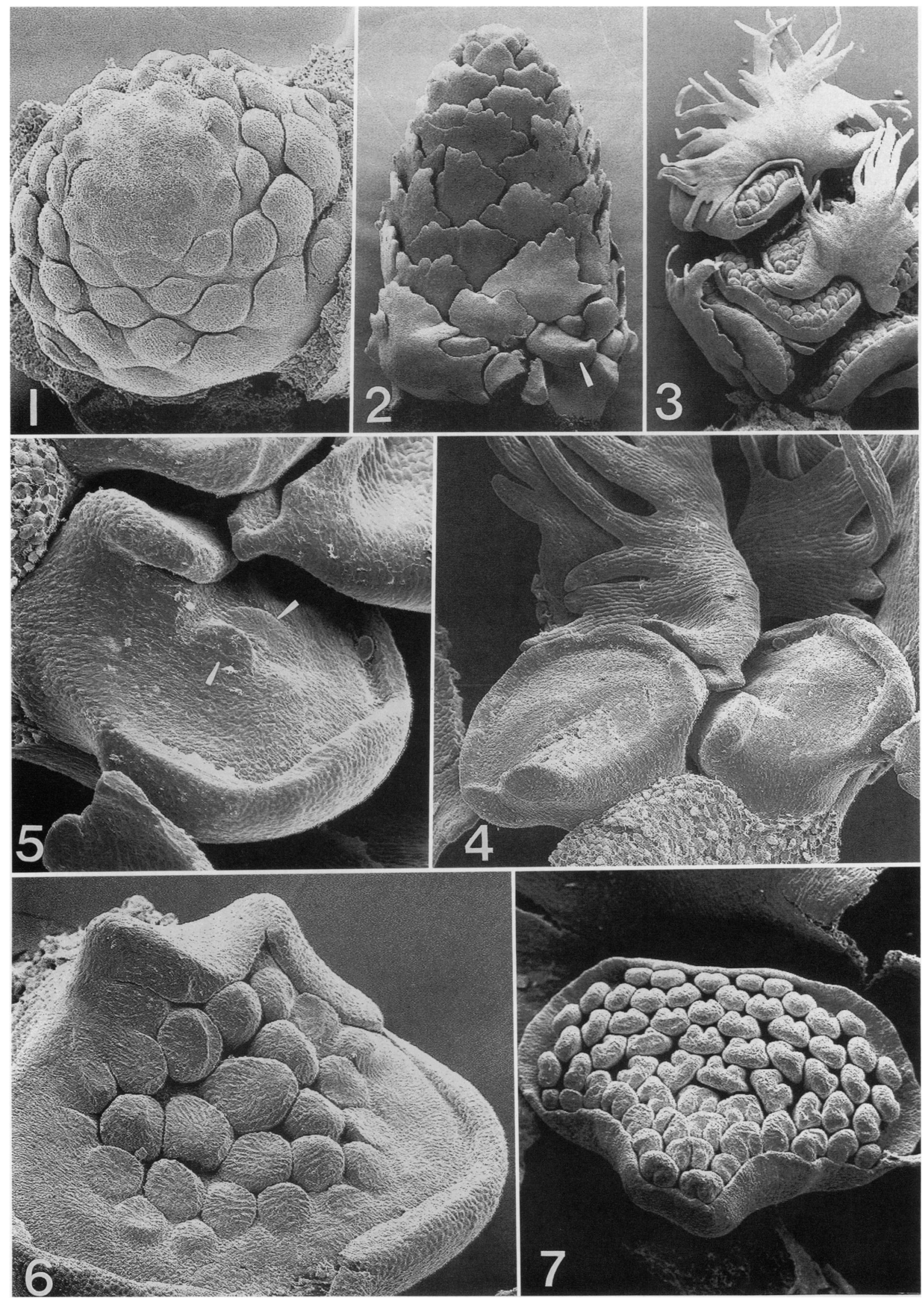



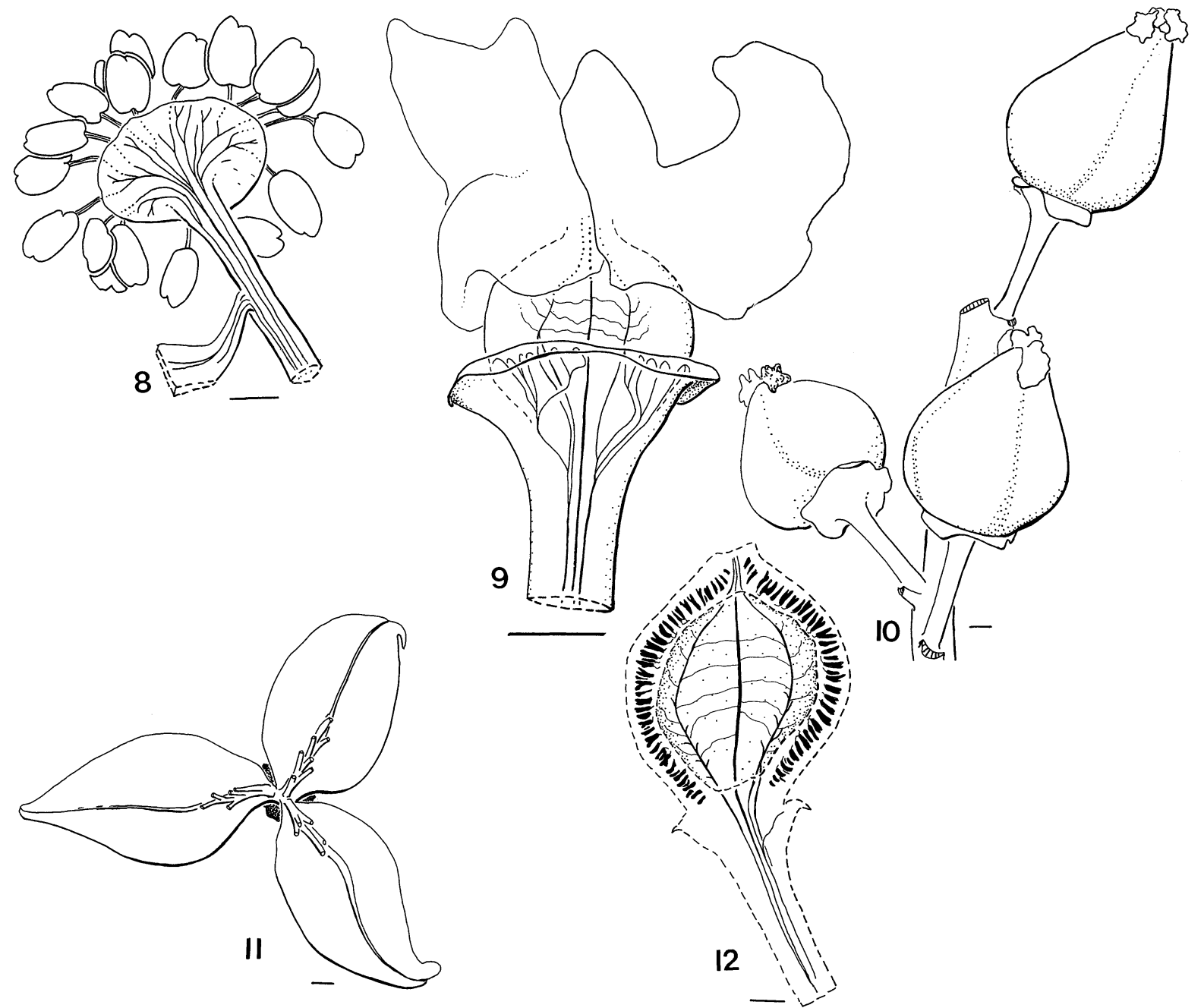

Figs. 8-12 Flowers and fruit. Scale bar $=1 \mathrm{~mm}$. Fig. 8, Cleared male flower in anthesis, April 8, as seen from below; xylem strands slightly simplified. Bundles of pedicel divide and serve first inner, then outer stamens, and finally perianth. Bract (only basal part shown) partially adnate to pedicel. Fig. 9, Female flower in anthesis, April 8, lateral view, with two stigmas shown; xylem strands slightly simplified and only those of the foreground tissues shown. Traces from pedicellar bundles serve perianth in three discrete systems; dorsal carpellary bundles are alternate with the perianth parts and branch repeatedly in the flaring stigma. One pair of ventral bundles is distally fused but basally separate and another is completely fused. Fig. 10, Three fruits nearing maturity; May 20; lines of dehiscence already evident; stigmas withered. Pericarp leaf-green and evenly covered with stomata at about the density of the stippling for the slightly indented sutures; perianth and pedicel lighter green. Bract scars evident. Fig. 11, Loculicidally dehisced capsule, the seeds with attached placental hairs having escaped, only the funiculi with their scars remaining; June 11. Fig. 12, Fruit halved in median longitudinal section, showing only the foreground representatives of the very numerous thick vein endings in the pericarp. Dorsal bundle in center; two sets of fused ventral bundles and their ovular traces shown. Only a few of many thin bundles connecting the dorsal and ventral bundles are shown; they provide traces that form the prominent vein endings. May 20.

Figs. 1-7 Development of male inflorescence and flower. Figs. 1-3, Male inflorescence. Fig. 1, Apical meristem of inflorescence with proximal bract primordia evident; June 10. $\times$ 98. Fig. 2, Floral primordia (arrow) evident in axils of lower bracts. Lobing and early fimbriation showing on bracts; June $22 . \times 46$. Fig. 3, Distal portion of inflorescence showing fimbriation of bracts and all anthers present; September 21. $\times$ 30. Figs. 4-7, Male flower. Fig. 4, Two floral primordia in adaxial view, the perianth already evident but only the barest suggestion of stamen primordia in the center of each receptacle; July $6 . \times 92$. Fig. 5 , First stamen primordium (arrow) near center of flower primordium; perianth primordia all evident; July 6 . $\times 276$. Fig. 6 , Most stamen primordia evident, the central ones distinctly more advanced and only the outermost yet to appear; August 21 . $\times 207$. Fig. 7, All stamens formed, their extrorse orientation now distinct, and the tepals collectively forming a cuplike perianth, having lost their individuality; September 21. $\times 86$. 


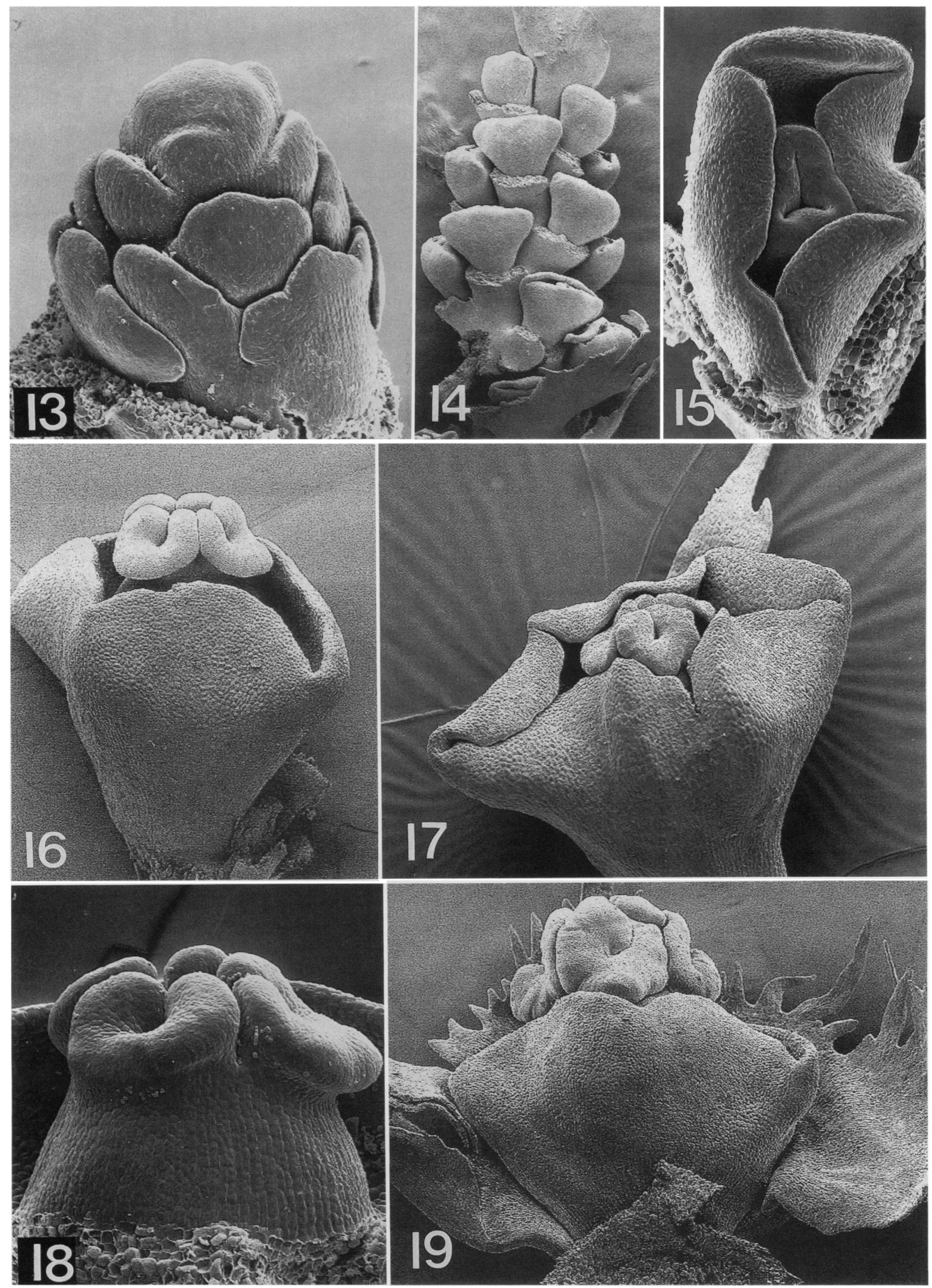

Figs. 13-19 Development of female inflorescence and flower. Figs. 13, 14, Inflorescence. Fig. 13, Primordium in early July; fewer than half the bract primordia evident, but the lowest ones already showing lobing that will lead to fimbriation; July 3 . $\times$ 40. Fig. 14, Bracts removed, lower floral primordia more advanced than upper; August 4. $\times$ 33. Figs. 15-19, Flowers. Fig. 
the laboratory always showed basipetal floral anthesis, but anther dehiscence within a flower varied depending upon which part of the flower was exposed: the exposed anthers dehisced first, regardless of their position in the flower. When neighboring flowers were removed and all anthers of a flower were exposed simultaneously, all dehisced simultaneously.

Androecial vasculature of the mature male flower is from three or four forking pedicellar trunk bundles that supply traces to stamens in sectors of the receptacle (fig. 8). The first traces to depart from the trunk bundles serve the firstformed, central stamens, and successively laterarising stamens are served by progressively more distal traces. Thus, the centrifugal pattern of stamen origin is reflected in the androecial vasculature. There is no external evidence of stamen fascicles during or after androecial ontogeny. The ultimate traces of the trunk bundles serve the perianth (fig. 8). The subtending bract, elevated from the rachis at anthesis, is independently vascularized, its trace running parallel to the pedicellar bundles for a short distance (fig. 8) and providing evidence of its adnation to the pedicel.

\section{FEMALE INFLORESCENCES AND FLOWERS}

ANTHESIS. The female inflorescence at anthesis is a crowded, more or less erect raceme that greatly elongates and becomes pendent after anthesis, as it becomes the infructescence. Each flower is subtended by a fimbriate bract like those of the male flowers, but the bracts remain sessile on the rachis and are not elevated when the flower ages as they are in the male inflorescences.

As the female inflorescence emerges from the axillary bud, the swelling flowers force apart the white, fimbriate bracts, which soon fall, exposing the light-green flaring stigmas and darker green ovary (fig. 9). Anthesis is in acropetal order on the raceme, which becomes pendent after pollination. The elongated rachis eventually hangs rather heavily with the weight of its green fruits (fig. 10).

OrganOGENESIS. A single floral primordium arises in the axil of each bract primordium, and all are evident by late July (fig. 13), although they are hidden by the imbricate scale primordia, which were dissected away (fig. 14). As the perianth primordia appear, the floral primordium as- sumes its dorsiventrally compressed, obturbinate shape (figs. 14, 17, 19). Usually, three unequal tepal primordia arise, two on the adaxial and a larger one on the abaxial side (figs. 15-17). They continue to grow as the floral primordium enlarges, and for a time they completely hide the developing gynoecium within (figs. 14, 15, 17).

Although a few flowers on my tree had two or four carpels, most flowers had three congenitally fused carpels (figs. 15-19, 23). The crescentshaped stigma primordia appear by autumn, and great stigmatic expansion and reflexing occurs just before anthesis the following April, creating a huge stigmatic surface relative to the size of the flower (figs. 9, 20). The anatropous ovules at anthesis are borne on thick, clavate funiculi (figs. 22, 23), but the coma-like placental hairs develop later. None of the flowers I examined from the tree studied bore stamens, but a few flowers from a nearby female tree did.

Three pedicellar bundles provide traces to the floral parts (fig. 9). Each of the three perianth parts receives a more or less dichotomizing system of traces, while a single dorsal bundle passes into each carpel, between two tepals, and finally into the stigma of that carpel, where it is joined by fine branches of the ventral bundles. The ventral bundles of adjacent carpels are usually free proximally but united distally, although sometimes they are completely united, and traces pass from them into the ovules. A network of slender bundles unites the dorsal with the ventral bundles and gives rise to numerous thickened vein endings in the pericarp as fruition progresses (fig. 12).

The green fruits enlarge quickly after pollination, their surface dense with stomata and their stigmas soon withering (figs. 10, 21). Losing their green color, the fruits dry in June and then dehisce loculicidally (fig. 11) in basipetal order on the raceme, each releasing about 18-40 seeds.

\section{Discussion}

In male and female inflorescences of Populus deltoides, flowers arise in acropetal order. Anthesis of female flowers is also in acropetal order, but anthesis of male flowers and fruit dehiscence are in basipetal order. Smith (1943) showed two sequences of meiosis in male catkins of Populus: a basipetal sequence, starting with the distal flowers, in Section Aigeiros (which includes $P$. deltoides), and an acropetal-basipetal sequence, starting near the middle of the catkin, in Sections

15, Typical three-carpellate flower primordium in polar view, the fused carpels evident but without stigmas, the three perianth parts still distinct but appearing as five because of folding; August 19. $\times 122$. Fig. 16, Young flower in lateral view, the stigmas now evident, the perianth still with its three parts distinct; March 23. $\times$ 84. Fig. 17, Folded perianth surrounding developing gynoecium; March 10. $\times$ 80. Fig. 18, Immature gynoecium with developing stigmas; March 23. $\times 150$. Fig. 19, Flower and its subtending bract, March 30, just before anthesis, the stigmas now enlarging rapidly. $\times 76$. 


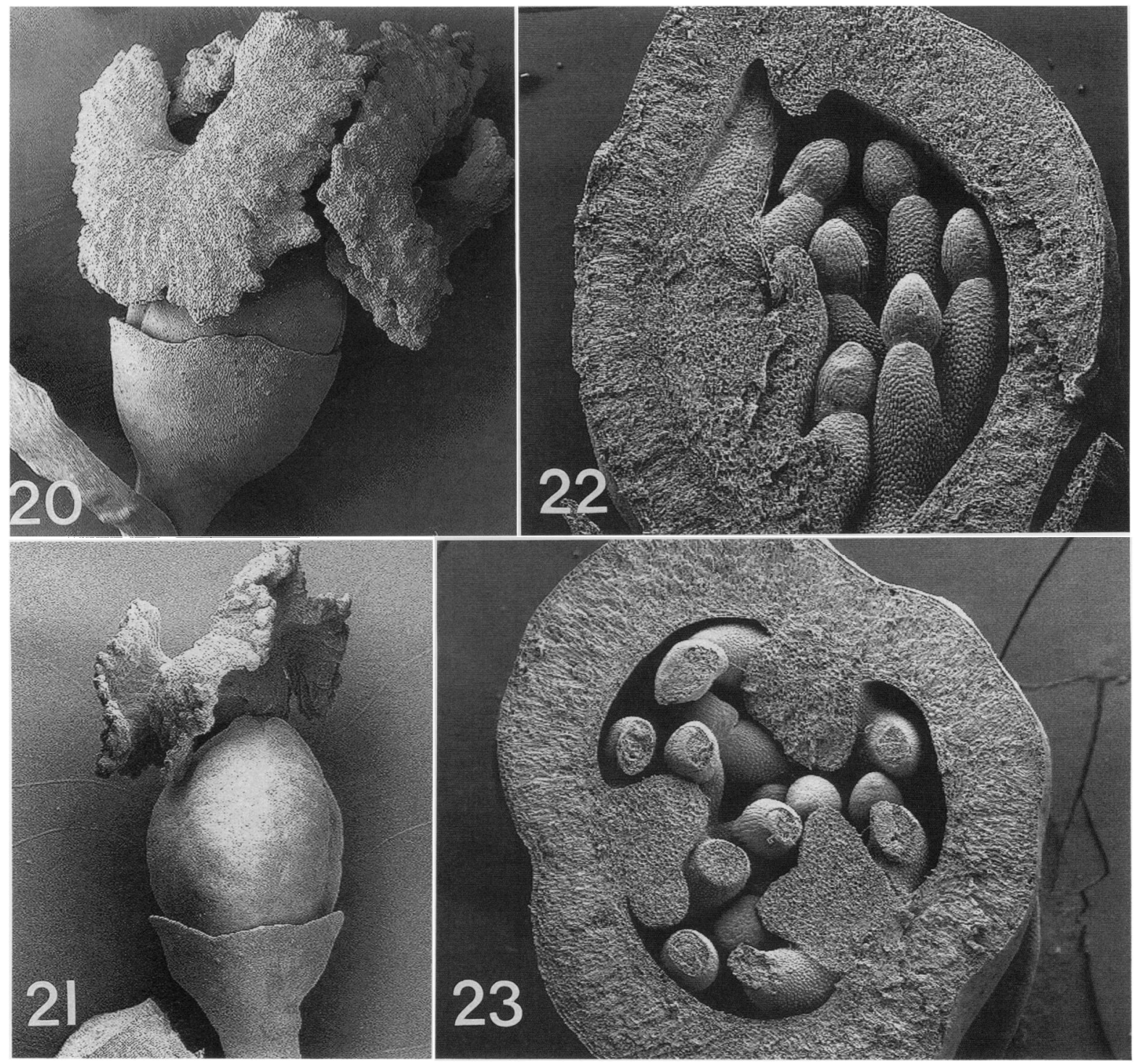

Figs. 20-23 Female flower. Fig. 20, Anthesis, April 10; the fully expanded stigmas now reflexed almost to the perianth and nearly hiding the ovary; perianth lobing now indistinct; base of floral bract shows in lower left corner. $\times 16$. Fig. 21 , Soon after anthesis, the ovary now enlarging and the stigmas withering; April 19. $\times 12$. Fig. 22, Longitudinally halved ovary, April 19 , soon after anthesis. The thick, clavate funiculi support the anatropous ovules, but the placental hairs are not yet forming. $\times$ 55. Fig. 23, Transversely halved gynoecium, April 19, soon after anthesis showing the three placentae and some ovules. $\times 55$.

Leuce and Tacamahaca; the meiotic sequences are subsequently repeated by the sequences of anther dehiscence in the catkin. My observations of $P$. deltoides are consistent with Smith's. It is not clear from any of these observations if or how these sequences have adaptive values. The basipetal anthesis of flowers of $P$. deltoides and its relatives in Section Aigeiros reflects their order of emergence from buds-distal flowers first, proximal last - and cause and effect might be inferred, the first flowers to emerge being the first to open. But other flowering sequences occur in species of other sections, e.g., Populus alba and Populus balsamifera, whose flowers emerge from their buds exactly as they do in P. deltoides- distal flowers first, proximal flowers last. Perhaps in species whose first male catkins appear slightly before the female, such as $P$. deltoides (Nagaraj 1952), the opening of the distal flowers upon their emergence from the bud, before the proximal flowers have emerged, extends the period of pollen rain. However, comparative observations from this and other species are insufficient to test that.

Even less clear is the significance, if any, of the basipetal order of fruit dehiscence on the infructescence, and comparative observations are few in the literature. The basipetal order possibly reflects only the general order of drying of the infructescence, distal parts first, and the consequent 
drying and opening of the capsules. I have observed that pattern in some but not in other species of Salix.

The male and female inflorescences are simple racemes, each flower being subtended by a bract. The inflorescence bracts are homologous with the cataphylls of the bud, as shown by their serial origin from the same apical meristem and by the frequent occurrence of intermediates, and the cataphylls themselves are homologous with foliage leaves (Curtis and Lersten 1974).

Homology of male to female flowers is indicated by their identical sites of origin on homologous inflorescences, their similar early organogenesis, and the occurrence of intersexual flowers and occasional flowers of one gender on inflorescences of the other. Strictly imperfect flowers are by far the commonest in Populus in general, but perfect and intersexual flowers are not unusual, occurring in at least nine species (Muhle Larson 1970).

Fisher (1928) considered Populus to have a true perianth, and my evidence supports that interpretation: although the perianth of male and female flowers of $P$. deltoides at anthesis appears to be a single ridge encircling the flower, its members arise separately and are vascularized independently. Other species, e.g., Populus pruinosa and Populus wilsonii, have a lobate perianth that more strongly resembles a typical perianth (Hjelmqvist 1948).

Centrifugal stamen origin in Populus was first reported by Hegelmaier (1880) and has since been verified in Populus canadensis (Graf 1921), P. deltoides (Nagaraj 1952), Populus tremuloides (Lester 1963; Sattler 1973), and Populus trichocarpa (Boes and Strauss 1994). Centrifugality is a derived state in angiosperms and has arisen numerous times in disparate families of monocotyledons and dicotyledons, often in conjunction with secondary polyandry in entomophilous plants (Ronse Decraene and Smets 1987, 1993). In angiosperms, anemophily has arisen repeatedly from entomophily, but anemophilous centrifugally polyandrous taxa such as Populus are few (cf. Ronse Decraene and Smets 1993). A clear assessment of the origin of anemophily and centrifugality in Populus is inhibited by the uncertain and seemingly isolated position of the Salicaceae and the consequent lack of closely related comparative groups, although centrifugality is present in the Flacourtiaceae, the family often cited as closest to the Salicaceae. The derived status of Populus relative to Salix, which is entomophilous and lacks centrifugal stamen inception, seems likely, however.

Hjelmqvist (1948) interpreted high stamen numbers (60-70 per flower) in Populus as the derived state, which is consistent with the derived status of secondary polyandry. More recently, Hong et al. (1987) found as many as 110 stamens per flower in Populus lasiocarpa in China, and some female flowers had five carpels; those authors designated it the most primitive species in the genus, but the opposite interpretation is indicated by comparative data presented here and in the literature. Eckenwalder's (1984b) cladistic analysis of Populus did not utilize stamen numbers as character states.

The plesiomorphic number of carpels in Populus is two if Salix and Flacourtiaceae are used as outgroups (Hjelmqvist 1948; Eckenwalder $1984 b$ ). Three carpels are typical of the flower of $P$. deltoides, but two- and four-carpellate flowers are easily found on my study tree and others. For the genus, the range is two to five (Hong et al. 1987; Boes and Strauss 1994). Thus, increased carpel number is the derived state, just as are increased stamen numbers. Whether species with higher stamen numbers also have higher carpel numbers is not evident from tabulated data in the literature survey of Boes and Strauss (1994).

The reproductive development and structure of Populus deltoides is best understood when compared with other species of Populus and with Salix, but the meager body of similar literature on Salix does not provide a broad-enough perspective of that large genus for meaningful comparisons with Populus. Likewise, clarification of the supposed relationship of Salicaceae to Flacourtiaceae, a large and mostly tropical family of shrubs and trees, is impeded by incomplete knowledge of its floral structure and development.

\section{Literature cited}

Bessey CE 1904 The number and weight of cottonwood seeds. Science 20:118-119.

Boes TK, SH Strauss 1994 Floral phenology and morphology of black cottonwood, Populus trichocarpa (Salicaceae). Am J Bot 81:562-567.

Christian B, S Charlette, D Christian 1993 Cytological and biochemical calendar of ovule and seed development in Populus sp. Plant Physiol 142:331-337.

Cronquist A 1988 The evolution and classification of flowering plants. 2d ed. New York Botanical Garden, New York. $555 \mathrm{pp}$.
Curtis JD, NR Lersten 1974 Morphology, seasonal variation, and function of resin glands on buds and leaves of Populus deltoides (Salicaceae). Am J Bot 61:835-845.

Eckenwalder JE $1984 a$ Natural intersectional hybridization between North American species of Populus (Salicaceae) in sections Aigeiros and Tacamahaca. II. Taxonomy. Can J Bot 62:325-335.

$1984 b$ Natural intersectional hybridization between North American species of Populus (Salicaceae) in sections Aigeiros and Tacamahaca. III. Paleobotany and evolution. Can J Bot 62:336-342. 
Farmer RE 1964 Sex ratio and sex-related characteristics in eastern cottonwood. Silvae Genet 13:116-118.

Fisher MJ 1928 The morphology and anatomy of the flowers of the Salicaceae, pt II. Am J Bot 15:372-394.

Graf J 1921 Beiträge zur Kenntniss der Gattung Populus. Beih Bot Centralblatt 38:405-454.

Hegelmaier Fr 1880 Ueber Blüthenentwicklung bei den Salicaceen. Württembergischen naturwissenschaftliche Jahreshefte, pp. 204-244.

Hejnowicz A 1976 Anatomy, embryology, and karyology of poplars. Pp. 117-147 in The poplars-Populus. Nasze Drzewa Leśne, Monografie Popularnonaukowe 12. Translation published by National Center for Scientific, Technical, and Economic Information, Warsaw, 1978, for USDA and National Science Foundation.

Hjelmqvist H 1948 Studies on the floral morphology and phylogeny of the Amentiferae. Bot Not 2(suppl):1-171.

Hong T, Ma Z-L, Chen J-S 1987 Floral morphology of Populus lasiocarpa Oliv. and its phylogenetic position in Populus. Acta Bot Sin 29:236-241.

Kaul RB, MN Kaul 1984 Sex ratios of Populus deltoides and Salix amygdaloides in Nebraska. Southwest Nat 29: 265-269.

Lester DT 1963 Floral initiation and development in quaking aspen. For Sci 9:323-329.

Little EL Jr 1971 Atlas of United States trees. I. Conifers and important hardwoods. Government Printing Office, Washington, D.C.

Meeuse ADJ 1975 Taxonomic relationships of Salicaceae and Flacourtiaceae: their bearing on interpretative floral morphology and dilleniid phylogeny. Acta Bot Neer 24: 437-457.

Muhle Larson C 1970 Recent advances in poplar breeding. Int Rev For Res 3:1-67.

Nagaraj M 1952 Floral morphology of Populus deltoides and P. tremuloides. Bot Gaz 114:222-243.

Ronse Decraene L-P, EF Smets 1987 The distribution and the systematic relevance of the androecial characters oligomery and polymery in the Magnoliophytina. Nord J Bot 7:239-253.

1993 The distribution and systematic relevance of the androecial character polymery. Bot J Linn Soc 113: 285-350.

Russell SD, M Rougier, C Dumas 1990 Organization of the early post-fertilization megagametophyte of Populus deltoides: ultrastructure and implications for male cytoplasmic transmission. Protoplasma 155:153-165.

Sattler R 1973 Organogenesis of flowers: a photographic text-atlas. University of Toronto Press, Toronto. $207 \mathrm{pp}$.

Smith EC 1943 A study of cytology and speciation in the genus Populus L. J Arnold Arbor Harv Univ 24:275-304.

Takhtajan A 1980 Outline of the classification of the flowering plants (Magnoliophyta). Bot Rev 46:225-359.

Thorne RF 1992 An updated phylogenetic classification of the flowering plants. Aliso 13:365-389.

Villar MM, M Gaget, C Said, RB Knox, C Dumas 1987 Incompatibility in Populus: structural and cytochemical characteristics of the receptive stigmas of Populus alba and P. nigra. J Cell Sci 87:483-490. 